\title{
KARAKTERISASI EKSTRAK KASAR FITASE TERMOFILIK DARI BAKTERI KAWAH IJEN BANYUWANGI, ISOLAT AP-17
}

\author{
Aline Puspita Kusumadjaja, Tutuk Budiati*, Sajidan**, dan Ni Nyoman Tri Puspaningsih*** \\ Jurusan Kimia Fakultas Matematika dan IImu Pengetahuan Alam Universitas Negeri Surabaya \\ *Fakultas Farmasi Universitas Airlangga Surabaya \\ ** Jurusan Pendidikan Matematika dan Ilmu Pengetahuan Alam Fakultas Keguruan dan Ilmu Pendidikan Universitas Negeri Sebelas Maret \\ ***Jurusan Kimia Fakultas Sain dan Teknologi Universitas Airlangga Surabaya \\ E-mail: aline_k4@yahoo.com
}

\begin{abstract}
Crude thermophilic phytase was produced by isolate AP-17 that has been isolated from Ijen Crater Banyuwangi. Based on Gram test, isolate AP-17 was gram positive spore forming rod shape bacteria so that it was identified as Bacillus sp. AP-17. Crude thermophilic phytase isolated from Bacillus sp. AP-17 had the optimum temperature at $75^{\circ} \mathrm{C}$ with activity of $0.1413 \mathrm{U} / \mathrm{ml}$, and its optimum $\mathrm{pH}$ was at $\mathrm{pH} 6$ with activity of $0.0875 \mathrm{U} / \mathrm{ml}$. The enzyme was stable when heated at $75^{\circ} \mathrm{C}$ for three hours and still had $90 \%$ activity when it was exposed at $\mathrm{pH}$ 5-8, optimum temperature, for one hour.
\end{abstract}

Key words: Bacillus sp. AP-17, crude thermophilic phytase, optimum temperature, optimum $p H$

\section{PENGANTAR}

Tanaman golongan serealia, biji-bijian dan leguminosa merupakan sumber pangan yang penting bagi kehidupan. Di samping sebagai sumber karbohidrat dan protein nabati, tanaman tersebut di atas juga mengandung serat, mineral maupun vitamin yang sangat dibutuhkan oleh makhluk hidup. Namun, selain kaya akan nutrisi, serealia, biji-bijian dan leguminosa juga mengandung senyawa anti gizi, yaitu asam fitat/garam fitat dalam jumlah yang cukup tinggi (Ozusaglam dan Ozcan, 2009).

Asam fitat dan garamnya merupakan bentuk utama penyimpanan mineral fosfor di dalam tanaman; sekitar 60-90\% total mineral fosfor tersimpan dalam bentuk asam fitat atau garam fitat (Greiner and Konietzny, 2006). Asam fitat/garamnya tidak termetabolisme secara sempurna dalam sistem pencernaan manusia maupun dalam saluran pencernaan hewan, khususnya hewan ternak. Asam fitat/ garamnya yang tidak termetabolisme ini menimbulkan beberapa masalah yaitu: menghambat daya cerna protein maupun ketersediaan biologis beberapa mineral penting, menimbulkan polusi lingkungan, serta menyebabkan kenaikan biaya produksi pakan ternak (Lott et al., 2000; Selle et al., 2000).

Salah satu cara untuk mengatasi masalah nutrisi dan lingkungan yang berkaitan dengan asam fitat/garamnya adalah dengan penggunaan enzim fitase pada proses pengolahan produk-produk pangan yang berbahan baku tanaman yang tinggi kandungan fitatnya, maupun pada proses pembuatan pakan ternak. Fitase atau mioinositol heksakisfosfat fosfohidrolase adalah enzim yang mengkatalisis reaksi hidrolisis ikatan fosfoester pada asam fitat (mio-inositol heksakisfosfat), menghasilkan fosfat anorganik dan ester-ester fosfat dari mio-inositol yang lebih rendah (Wang et al., 2004)

Dewasa ini, fitase telah dimanfaatkan pada industri pangan dan industri pakan ternak. Berkaitan dengan pemanfaatannya pada industri, penggunaan enzim fitase termofilik pada industri pangan dan industri pakan ternak sangat menguntungkan. Hal ini disebabkan berbagai proses pengolahan bahan pangan maupun proses pembuatan pelet pakan ternak menggunakan suhu tinggi. Fitase termofilik memiliki aktivitas optimal dan kestabilan termal yang baik pada suhu tinggi (Gulati et al., 2007).

Pada penelitian ini telah dilakukan penentuan suhu, $\mathrm{pH}$ optimum, stabilitas termal maupun stabilitas pH ekstrak kasar fitase termofilik, dari isolat Kawah Ijen Banyuwangi yang berkode AP-17. Isolat AP-17 mampu menghasilkan fitase dengan aktivitas tertinggi dibandingkan isolat-isolat Kawah Ijen lainnya, sehingga isolat ini digunakan untuk penelitian lebih lanjut. Identifikasi isolat AP-17 dilakukan melalui uji pewarnaan Gram. Berdasarkan uji pewarnaan Gram, isolat AP-17 termasuk bakteri Gram positif yang memiliki sel berbentuk batang dengan endospora yang terletak secara subterminal. Isolat AP-17 diidentifikasi merupakan kelompok Bacillus sehingga isolat ini selanjutnya disebut Bacillus sp. AP-17.

Karakterisasi ekstrak kasar fitase termofilik hasil isolasi dari Bacillus sp. AP-17 meliputi penentuan suhu optimum, $\mathrm{pH}$ optimum serta penentuan stabilitas termal dan stabilitas $\mathrm{pH}$. Penentuan suhu optimum dan $\mathrm{pH}$ optimum 
enzim dilakukan dengan mengukur aktivitas enzim pada kisaran suhu 55-90 ${ }^{\circ} \mathrm{C}$, dan kisaran $\mathrm{pH}$ yaitu $\mathrm{pH}$ 2-9. Penelitian mengenai stabilitas termal dilakukan dengan cara memanaskan enzim pada suhu $75^{\circ} \mathrm{C}, 85^{\circ} \mathrm{C}$, dan $90^{\circ} \mathrm{C}$, setiap selang waktu tertentu. Penentuan stabilitas $\mathrm{pH}$ dilakukan dengan cara mengukur aktivitas enzim pada kondisi optimum setelah enzim tersebut dipaparkan pada berbagai harga $\mathrm{pH}$ yaitu $\mathrm{pH}$ 2-9.

\section{BAHAN DAN CARA KERJA}

\section{Bahan}

Bahan-bahan kimia yang digunakan mempunyai kualitas pro-analisis (pa), antara lain bacto-tryptone, bactoagar, yeast extract, $\mathrm{NaCl}$, glukosa, Na-fitat, $\mathrm{CaCl}_{2} \cdot \mathrm{H}_{2} \mathrm{O}$, $\mathrm{NH}_{4} \mathrm{NO}_{3}, \mathrm{KCl}, \mathrm{MgSO}_{4} \cdot 7 \mathrm{H}_{2} \mathrm{O}, \mathrm{FeSO}_{4} \cdot 7 \mathrm{H}_{2} \mathrm{O}, \mathrm{MnSO}_{4} \cdot \mathrm{H}_{2} \mathrm{O}$, amonium molibdat, ammonium vanadat, $\mathrm{KH}_{2} \mathrm{PO}_{4}$, kristal violet, alkohol, lugol, safranin, TCA, asam nitrat pekat.

\section{Galur dan Media Pertumbuhan}

Galur yang digunakan pada penelitian ini adalah isolat AP-17 yang dihasilkan dari proses screening mikroorganisme termofilik Kawah Ijen Banyuwangi, media Luria Bertani (LB), media screening fitase (Keruvou et al., 1998). Komposisi media LB cair adalah: bacto-tryptone $1 \%(\mathrm{~b} / \mathrm{v})$, yeast extract 0,5\% (b/v), dan $\mathrm{NaCl} 1 \%(\mathrm{~b} / \mathrm{v})$. Komposisi media LB padat sama dengan media LB cair hanya pada media LB padat ditambahkan bacto-agar 2\% (b/v). Komposisi media cair untuk screening fitase adalah: glukosa $2 \%$ (b/v), Na-fitat 0,4\% (b/v), $\mathrm{CaCl}_{2} 0,2 \%$ (b/v), $\mathrm{NH}_{4} \mathrm{NO}_{3} 0,5 \%$ (b/v), $\mathrm{KCl} 0,05 \%$ (b/v), $\mathrm{MgSO}_{4} \cdot 7 \mathrm{H}_{2} \mathrm{O} 0,05 \%$ (b/v), bacto-tryptone 1,5\% (b/v), $\mathrm{FeSO}_{4} .7 \mathrm{H}_{2} \mathrm{O}$ 0,001\% (b/v), dan $\mathrm{MnSO}_{4} \cdot \mathrm{H}_{2} \mathrm{O}$ 0,001\% (b/v). Komposisi media padat untuk screening fitase sama dengan media screening cair hanya pada media screening padat ditambahkan bactoagar $2 \%(\mathrm{~b} / \mathrm{v})$.

\section{Alat}

Shaker incubator, incubator, spektrofotometer UVVIS, sentrifus.

\section{Cara Kerja \\ Pewarnaan Gram}

Koloni tunggal isolat AP-17 dioleskan di atas preparat. Tiga gram kristal violet yang sudah dilarutkan dalam $100 \mathrm{ml}$ alkohol dan aquadest $900 \mathrm{ml}$, diteteskan sebanyak $3 \mathrm{ml}$ di atas preparat dan didiamkan selama 2 menit. Mikroorganisme yang sudah ditetesi kristal violet selanjutnya ditetesi lugol di atasnya, dilanjutkan dengan alkohol sebanyak $3 \mathrm{ml}$ lalu preparat dicuci dengan aquadest. Sebanyak $3 \mathrm{ml}$ safranin diteteskan di atas preparat dan didiamkan selama 1 menit. Kemudian preparat dibasuh kembali dengan aquadest dan diletakkan dalam posisi miring untuk mempercepat pengeringan. Setelah preparat kering, diamati dengan mikroskop.

\section{Produksi Ekstrak Kasar Fitase Termofilik dari Isolat AP-17}

Koloni tunggal AP-17 ditumbuhkan pada $100 \mathrm{ml}$ media screening cair, pada suhu $52^{\circ} \mathrm{C}$ dengan pengocokan menggunakan shaker incubator kecepatan $200 \mathrm{rpm}$ selama 18 jam. Suspensi disentrifus dengan kecepatan $4000 \mathrm{rpm}$ suhu $4^{\circ} \mathrm{C}$ selama 15 menit. Supernatan yang diperoleh merupakan ekstrak kasar fitase.

\section{Penentuan Aktivitas Ekstrak Kasar Fitase Termofilik}

Metode yang digunakan pada penentuan aktivitas fitase adalah metode dari Wang et al., 2004, dengan sedikit modifikasi. Penentuan aktivitas enzim dilakukan dengan $3 \times$ pengulangan. Masing-masing $1 \mathrm{ml}$ larutan ekstrak kasar enzim diinkubasi dengan $1 \mathrm{ml}$ Na-fitat $2 \mathrm{mM}$ yang mengandung $\mathrm{CaCl}_{2} 1 \mathrm{mM}$, pada suhu $50^{\circ} \mathrm{C}$ selama 15 menit. Berikutnya ditambahkan $2 \mathrm{ml}$ TCA 5\%, dan setiap campuran enzim-substrat didiamkan pada suhu $4^{\circ} \mathrm{C}$ selama 15 menit. Kemudian disentrifugasi dengan kecepatan $4.000 \mathrm{rpm}$ selama 20 menit. Sebanyak $2 \mathrm{ml}$ supernatan direaksikan dengan $2 \mathrm{ml}$ reagen molibdat-vanadat, dan diukur absorbansinya menggunakan spektrofotometer UVVis, pada panjang gelombang $392 \mathrm{~nm}$.

\section{Karakterisasi Ekstrak Kasar Fitase Termofilik}

Karakterisasi ekstrak kasar fitase meliputi penentuan suhu optimum, $\mathrm{pH}$ optimum, stabilitas termal, dan stabilitas $\mathrm{pH}$.

Penentuan suhu optimum enzim dilakukan dengan cara menentukan aktivitas enzim pada berbagai suhu, yaitu 55-90 ${ }^{\circ}$ C. Penentuan $\mathrm{pH}$ optimum enzim dilakukan dengan cara menentukan aktivitas enzim pada berbagai $\mathrm{pH}$ yaitu dari pH 2-9.

Stabilitas termal enzim ditentukan dengan cara memanaskan enzim pada suhu optimumnya, dan pada selang waktu tertentu ditentukan aktivitasnya sampai enzim tidak memperlihatkan aktivitas secara signifikan. Penentuan stabilitas $\mathrm{pH}$ dilakukan dengan cara melarutkan enzim dalam larutan bufer dengan berbagai harga $\mathrm{pH}$. Setiap campuran reaksi ini diinkubasi selama 1 jam pada suhu $75^{\circ} \mathrm{C}$. Setelah itu dilakukan penentuan aktivitas enzim pada $\mathrm{pH}$ optimum dan suhu optimum. 


\section{Analisis Data}

Satu unit aktivitas enzim fitase didefinisikan sebagai jumlah enzim yang mengkatalisis reaksi yang menghasilkan $1,0 \mu \mathrm{mol}$ fosfat anorganik per menit pada kondisi optimum (Boyce et al., 2004). Penentuan konsentrasi fosfat anorganik dilakukan dengan menggunakan pereaksi amonium molibdat-vanadat. Kemudian diukur absorbansinya dengan spektrofotometer UV-VIS pada panjang gelombang $392 \mathrm{~nm}$. Larutan $\mathrm{KH}_{2} \mathrm{PO}_{4}$ digunakan untuk pembuatan kurva kalibrasi pada penentuan konsentrasi fosfat anorganik.

Data yang diperoleh pada uji pewarnaan Gram diamati dengan mikroskop. Data yang diperoleh pada tahap karakterisasi enzim, yaitu $\mathrm{pH}$ optimum, suhu optimum, kestabilan termal, dan kestabilan $\mathrm{pH}$, dianalisis secara deskriptif kuantitatif.

\section{HASIL}

Hasil uji pewarnaan Gram isolat AP-17 diilustrasikan pada Gambar 1. Isolat AP-17 merupakan bakteri Gram positif berbentuk batang dan memiliki endospora berbentuk oval yang terletak subterminal.

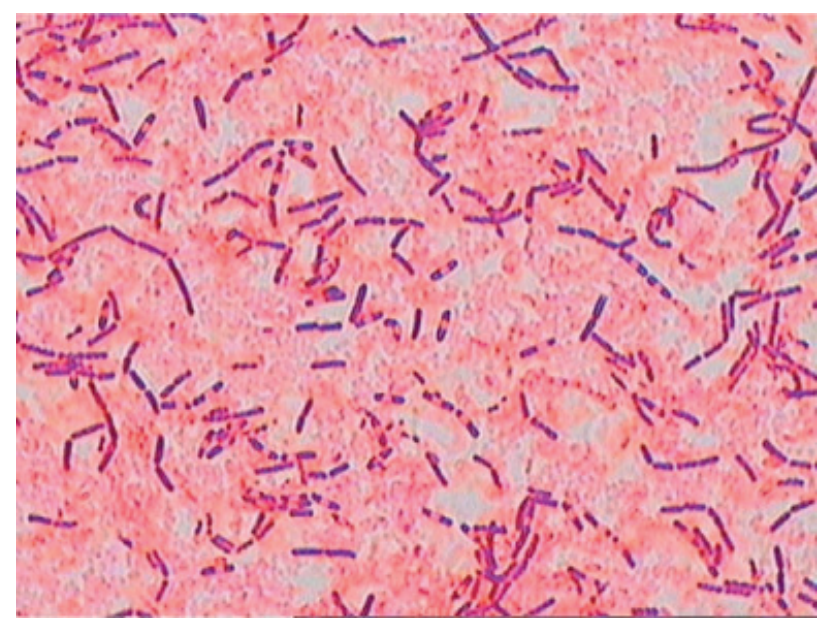

Gambar 1. Hasil pewarnaan isolat AP-17. Sel bakteri berbentuk batang dan memiliki endospora.

Hubungan antara aktivitas enzim dengan berbagai suhu inkubasi diilustrasikan pada Gambar 2. Ekstrak kasar fitase termofilik memiliki suhu optimum $75^{\circ} \mathrm{C}$ dengan aktivitas sebesar 0,1413 U/ml.

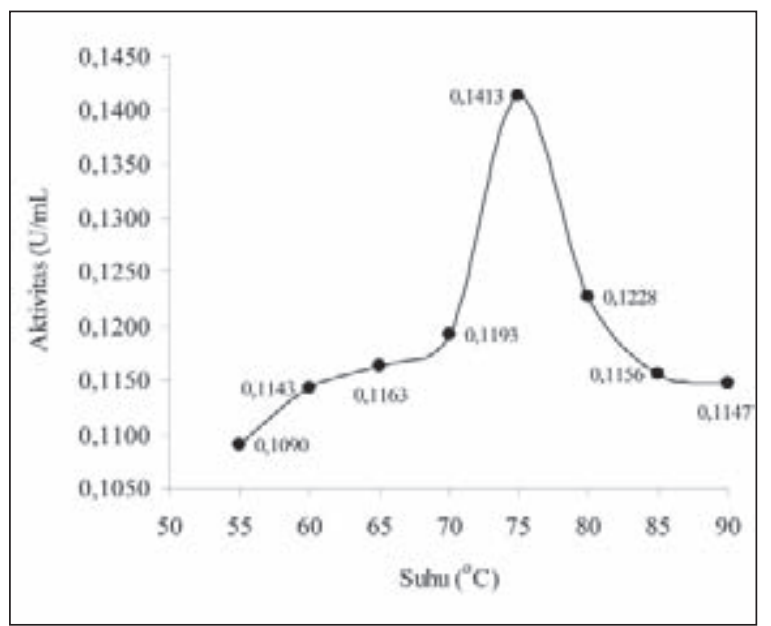

Gambar 2. Kurva aktivitas ekstrak kasar fitase termofilik pada berbagai suhu inkubasi

Hubungan antara aktivitas enzim dengan berbagai harga $\mathrm{pH}$ diilustrasikan pada Gambar 3. Ekstrak kasar fitase termofilik memiliki $\mathrm{pH}$ optimum 6 dengan aktivitas sebesar $0,0875 \mathrm{U} / \mathrm{ml}$.

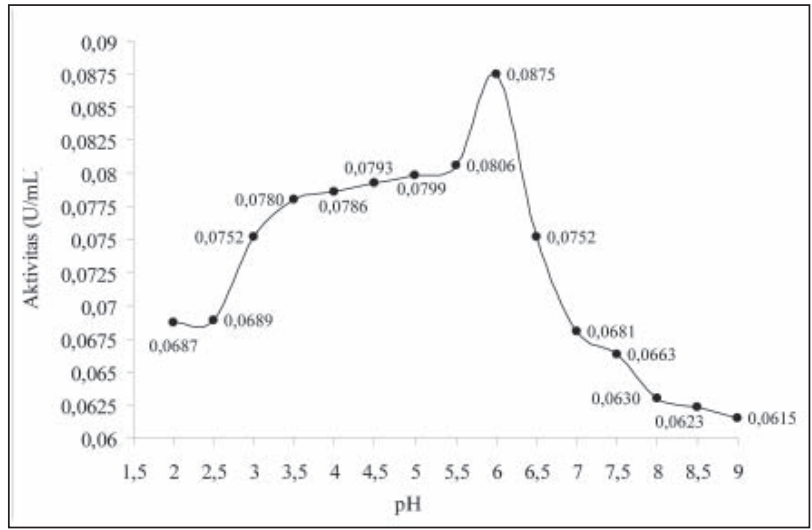

Gambar 3. Kurva aktivitas ekstrak kasar fitase termofilik pada berbagai $\mathrm{pH}$

Hubungan antara aktivitas enzim dengan waktu pemanasan pada suhu $75^{\circ} \mathrm{C}$ diilustrasikan pada Gambar 4 . Setelah pemanasan selama 3 jam pada suhu $75^{\circ} \mathrm{C}$, ekstrak kasar fitase termofilik masih memiliki aktivitas sebesar $60 \%$. Aktivitas enzim yang tersisa setelah pemanasan selama 6 jam pada suhu $75^{\circ} \mathrm{C}$ adalah sebesar $32 \%$. 


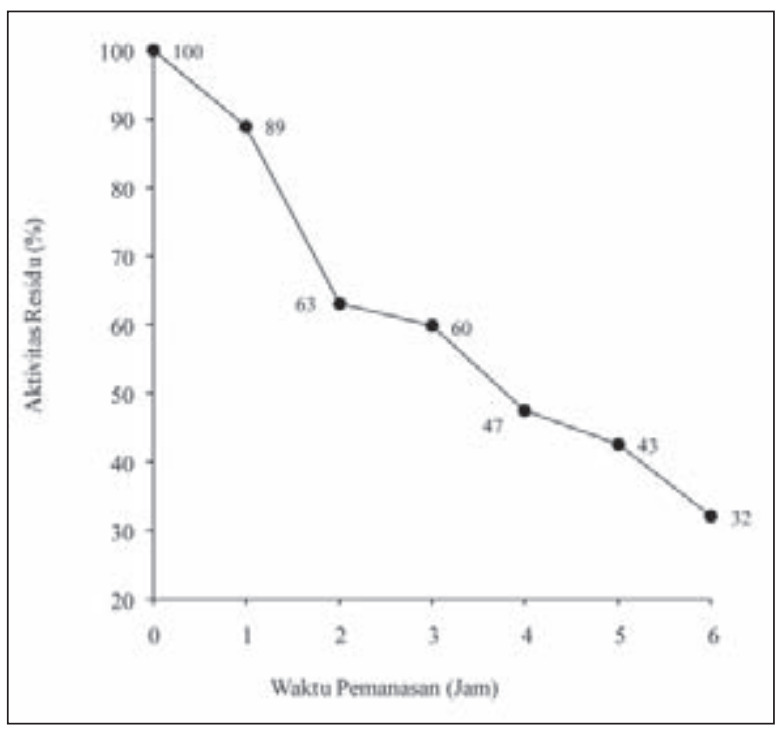

Gambar 4. Kurva yang menggambarkan aktivitas residu setelah pemanasan suhu $75^{\circ} \mathrm{C}$ pada berbagai lama waktu pemanasan

Hubungan antara aktivitas enzim dengan waktu pemanasan pada suhu $85^{\circ} \mathrm{C}$ dan $95^{\circ} \mathrm{C}$ diilustrasikan pada Gambar 5. Setelah pemanasan selama 20 menit pada suhu $85^{\circ} \mathrm{C}$, ekstrak kasar fitase termofilik masih memiliki aktivitas sebesar $58 \%$, sedangkan pemanasan selama 20 menit pada suhu $95^{\circ} \mathrm{C}$ menyebabkan aktivitas yang tersisa sebesar $43 \%$. Setelah pemanasan selama 80 menit pada suhu $85^{\circ} \mathrm{C}$, aktivitas enzim yang tersisa sebesar $39 \%$, sedangkan pemanasan selama 80 menit pada suhu $95^{\circ} \mathrm{C}$ menyebabkan aktivitas yang tersisa sebesar $25 \%$.

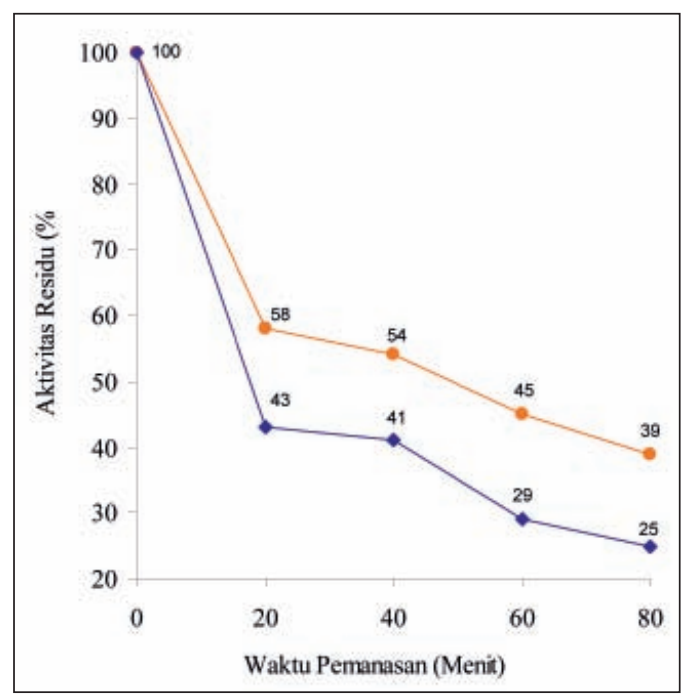

Gambar 5. Kurva yang menggambarkan aktivitas residu setelah pemanasan pada suhu $85^{\circ} \mathrm{C}(\bullet)$ dan $95^{\circ} \mathrm{C}(\diamond)$ pada berbagai lama waktu pemanasan
Aktivitas enzim yang tersisa setelah pemanasan pada suhu $75^{\circ} \mathrm{C}$ selama 1 jam pada berbagai harga $\mathrm{pH}$ diilustrasikan pada Gambar 6. Setelah enzim dipaparkan pada kisaran $\mathrm{pH}$ 5-8, pada suhu optimum selama 1 jam, aktivitas enzim yang tersisa lebih dari 90\%. Ketika enzim dipaparkan pada $\mathrm{pH} 4$ aktivitas enzim yang tersisa sebesar 43\%, sedangkan ketika enzim dipaparkan pada pH 2-3 maupun pada $\mathrm{pH} 9$, aktivitas enzim yang tersisa hanya sekitar $40 \%$.

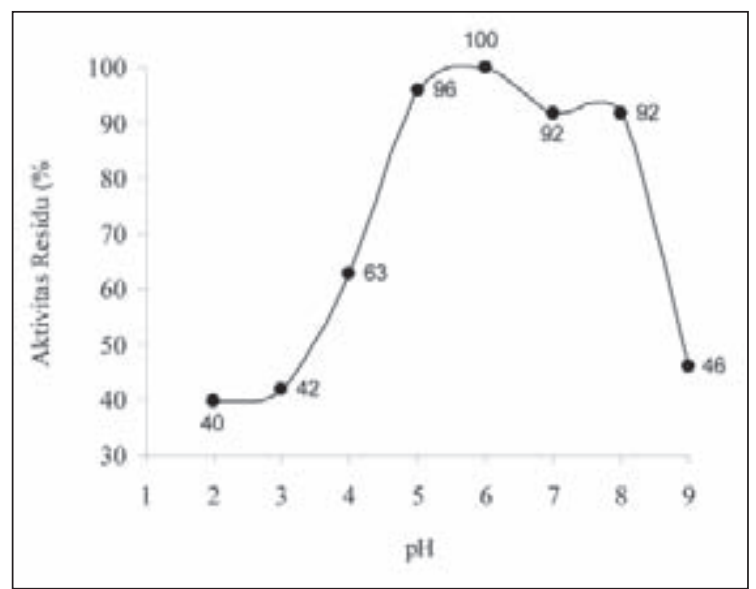

Gambar 6. Kurva yang menggambarkan aktivitas residu setelah pemanasan pada suhu $75^{\circ} \mathrm{C}$ selama 1 jam pada berbagai harga $\mathrm{pH}$

\section{PEMBAHASAN}

\section{Karakterisasi Isolat AP-17}

Isolat AP-17 memiliki karakteristik koloni sebagai berikut: berwarna putih, berbentuk bulat, tepi tidak rata, memiliki elevasi yang rata, dan tidak tembus cahaya. Selain pengamatan terhadap karakterisitik koloni, dilakukan pula uji pewarnaan Gram terhadap isolat AP-17.

Hasil uji pewarnaan Gram isolat AP-17 seperti diilustrasikan pada Gambar 1, menunjukkan bahwa sel bakteri isolat AP-17 berbentuk batang dan berwarna ungu serta memiliki endospora berbentuk oval yang terletak secara subterminal. Berdasarkan hasil yang teramati pada uji pewarnaan Gram, maka isolat AP-17 digolongkan sebagai bakteri Gram positif dan diidentifikasi sebagai bakteri golongan Bacillus. Isolat ini dengan demikian disebut Bacillus sp. AP-17.

Warna ungu yang timbul pada sel bakteri isolat AP17 sehingga isolat ini digolongkan sebagai bakteri Gram positif, disebabkan kompleks zat pewarna kristal violet-lugol terperangkap di antara dinding sel dan membran sitoplasma bakteri dan zat pewarna ini tetap bertahan walaupun dicuci 
dengan alkohol (Barrow dan Feltham, 1993). Sementara itu, pada sel bakteri Gram negatif, pencucian dengan alkohol menyebabkan terjadinya penyingkiran lipida dari dinding selnya, dan juga lepasnya zat pewarna kristal violet-lugol. Oleh karena bakteri gram negatif tidak berwarna setelah dicuci dengan alkohol, maka diberikan zat warna lain sebelum diamati di bawah mikroskop. Zat pewarna lain itu biasanya ialah zat pewarna merah safranin, dan karena itu bakteri gram negatif berwarna merah.

\section{Karakterisasi Ekstrak Kasar Fitase Termofilik}

Karakterisasi ekstrak kasar fitase termofilik hasil isolasi dari Bacillus sp AP-17 meliputi penentuan suhu optimum, $\mathrm{pH}$ optimum, stabilitas termal, dan stabilitas $\mathrm{pH}$.

Suhu optimum adalah suhu pada saat aktivitas enzim mencapai nilai tertinggi. Hasil penelitian mengenai suhu optimum enzim diilustrasikan pada Gambar 2. Aktivitas ekstrak kasar fitase termofilik mengalami kenaikan seiring dengan peningkatan suhu dari $55^{\circ} \mathrm{C}$ hingga $75^{\circ} \mathrm{C}$, sedangkan kenaikan suhu di atas suhu $75^{\circ} \mathrm{C}$ menyebabkan penurunan aktivitas enzim. Aktivitas tertinggi dicapai pada suhu $75^{\circ} \mathrm{C}$ yaitu sebesar 0,1413 U/ml.

Kenaikan suhu di atas suhu $75^{\circ} \mathrm{C}$ yang merupakan suhu optimum enzim akan menurunkan aktivitas enzim. Pemanasan di atas suhu $75^{\circ} \mathrm{C}$ menyebabkan terjadinya perubahan konformasi enzim yang mengarah pada perubahan destruktif. Ikatan-ikatan kovalen yang mempertahankan struktur sekunder dan tersier enzim putus sehingga terjadi kerusakan pada molekul enzim (Berg et al., 2006). Kerusakan inilah yang mengakibatkan turunnya aktivitas enzim.

Beberapa fitase mikroba yang telah diteliti memiliki suhu optimum berkisar antara $40^{\circ} \mathrm{C}$ hingga $70^{\circ} \mathrm{C}$. Fitase dari E. coli memiliki suhu optimum $55^{\circ} \mathrm{C}$ (Grener et al.,1993), sedangkan fitase dari Bacillus sp. DS 11 memiliki suhu optimum $70^{\circ} \mathrm{C}$ (Kim et al., 1998). Fitase dari B. laevolacticus memiliki suhu optimum $70^{\circ} \mathrm{C}$ (Gulati et al., 2007). Fitase Sporotrichum thermophile memiliki aktivitas tertinggi pada suhu $60^{\circ} \mathrm{C}$ (Singh dan Satyanarayana, 2009). Fitase dari isolat AP-17 dengan demikian memiliki suhu optimum yang lebih tinggi dibandingkan fitase-fitase tersebut di atas dan memilliki potensi yang baik untuk digunakan pada industri pakan ternak maupun industri pangan.

$\mathrm{pH}$ optimum enzim adalah $\mathrm{pH}$ pada saat aktivitas enzim mencapai nilai tertinggi. Hasil penelitian mengenai pH optimum ekstrak kasar fitase termofilik diilustrasikan pada Gambar 3. Aktivitas enzim mengalami kenaikan pada $\mathrm{pH} 2$ hingga 6, kemudian turun pada $\mathrm{pH} 7$ hingga 9. Nilai aktivitas tertinggi dicapai pada $\mathrm{pH}$ 6, yaitu sebesar $0,0875 \mathrm{U} / \mathrm{ml}$.
pH sangat berpengaruh terhadap aktivitas enzim. Enzim merupakan protein yang tersusun atas residu-residu asam amino. Perubahan $\mathrm{pH}$ menyebabkan perubahan muatan pada residu-residu asam amino, terutama yang menyusun pusat aktif enzim. Hal ini sangat berpengaruh terhadap konformasi enzim, daya katalitik dan efisiensi pengikatan enzim-substrat (Nelson dan Cox, 2000).

Aktivitas ekstrak kasar fitase termofilik mencapai nilai tertinggi pada $\mathrm{pH}$ 6. Pada $\mathrm{pH}$ optimum tersebut, enzim berada pada tingkat ionisasi yang paling sesuai untuk berikatan dengan substrat. Konformasi enzim dalam bentuk yang sangat stabil sehingga meningkatkan efektivitas pengikatan enzim-substrat (Nelson dan Cox, 2000). Perubahan $\mathrm{pH}$ di sekitar $\mathrm{pH}$ optimum menyebabkan berubahnya muatan residu-residu asam amino, terutama yang menyusun pusat aktif enzim. Hal ini menyebabkan turunnya efektivitas pengikatan-pengikatan enzim-substrat sehingga perubahan $\mathrm{pH}$ di sekitar $\mathrm{pH} 6$ menyebabkan turunnya aktivitas enzim.

Enzim fitase mikrobial, terutama dari fungi, memiliki pH optimum 4,5 hingga 5,6. Fitase dari A. fumigatus memiliki kisaran $\mathrm{pH}$ optimum yang luas, yaitu antara 4,0 hingga 7,3 (Wyss et al., 1999), sedangkan fitase A. niger memiliki dua $\mathrm{pH}$ optimum yaitu $\mathrm{pH}$ 2,5 dan $\mathrm{pH}$ 5-5,5 (Kim et al., 2006). Fitase bakteri, terutama dari golongan Bacillus, memiliki pH optimum antara 6,0 hingga 7,5.

Stabilitas termal ekstrak kasar fitase termofilik diilustrasikan pada Gambar 4. Ekstrak kasar fitase termofilik masih memiliki aktivitas sebesar $60 \%$ setelah dipanaskan pada suhu $75^{\circ} \mathrm{C}$ selama 3 jam, sedangkan pemanasan selama 6 jam pada suhu $75^{\circ} \mathrm{C}$ menyebabkan aktivitas yang tersisa adalah $32 \%$.

Hubungan antara aktivitas enzim dengan waktu pemanasan pada suhu $85^{\circ} \mathrm{C}$ dan $95^{\circ} \mathrm{C}$ diilustrasikan pada Gambar 5. Pemanasan selama 20 menit pada suhu $85^{\circ} \mathrm{C}$ menyebabkan aktivitas enzim yang tersisa sebesar 58\%, sedangkan pemanasan selama 20 menit pada suhu $95^{\circ} \mathrm{C}$ menyebabkan aktivitas yang tersisa hanya sebesar $43 \%$. Sementara itu, pemanasan selama 80 menit pada suhu $85^{\circ} \mathrm{C}$ menyebabkan aktivitas enzim yang tersisa sebesar $39 \%$, sedangkan pemanasan pada suhu $95^{\circ} \mathrm{C}$ selama 80 menit menyebabkan enzim hanya memiliki aktivitas sebesar $25 \%$.

Di dalam larutan $5 \mathrm{mM} \mathrm{CaCl}_{2}$, fitase dari Bacillus sp. DS 11 masih memiliki aktivitas 100\% setelah diinkubasi selama 10 menit pada suhu $70^{\circ} \mathrm{C}$, dan aktivitas enzim yang tersisa sebesar 50\% setelah diinkubasi selama 10 menit pada suhu $90^{\circ} \mathrm{C}$ (Kim et al., 1998). Fitase termofilik dari B. laevolacticus masih memiliki aktivitas sebesar $80 \%$ 
setelah diinkubasi selama 3 jam pada pH 8 dan suhu $70^{\circ} \mathrm{C}$ (Gulati et al., 2007).

Ekstrak kasar fitase memiliki kestabilan yang baik pada kisaran $\mathrm{pH}$ yang luas. Seperti diilustrasikan pada Gambar 6, aktivitas enzim yang tersisa lebih dari 90\% setelah enzim dipaparkan pada kisaran $\mathrm{pH}$ 5-8, pada suhu optimum selama 1 jam. Ketika enzim dipaparkan pada pH 4 aktivitas enzim yang tersisa sebesar 43\%, sedangkan ketika enzim dipaparkan pada $\mathrm{pH}$ 2-3 maupun pada $\mathrm{pH} 9$, aktivitas enzim yang tersisa hanya sekitar $40 \%$. Fitase dari Bacillus sp. DS 11 memiliki kestabilan yang baik pada kisaran $\mathrm{pH}$ 4-8.

Kesimpulan dari penelitian ini adalah: berdasarkan uji pewarnaan gram, isolat AP-17 diduga merupakan bakteri kelompok Bacillus, ekstrak kasar fitase termofilik hasil isolasi dari Bacillus sp. AP-17 memiliki suhu optimum $75^{\circ} \mathrm{C}$ dengan aktivitas 0,1413 U/ml, ekstrak kasar fitase termofilik hasil isolasi dari Bacillus sp. AP-17 memiliki pH optimum pada $\mathrm{pH} 6$ dengan aktivitas $0,0875 \mathrm{U} / \mathrm{ml}$, ekstrak kasar fitase termofilik stabil pada pemanasan suhu $75^{\circ} \mathrm{C}$ selama $3 \mathrm{jam}$. Hal ini ditunjukkan dengan aktivitas enzim yang masih sebesar $60 \%$ setelah proses pemanasan tersebut, ekstrak kasar fitase termofilik masih memiliki aktivitas sebesar 90\% ketika enzim dipaparkan pada kisaran pH 5-8 pada suhu optimum selama 1 jam.

\section{KEPUSTAKAAN}

Barrow GI dan Feltham RKA, 1993. Cowan and Steel's Manual for The Identification of Medical Bacteria, $3^{\text {rd }}$ ed, Cambridge University Press, New York.

Berg JM, Tymoczko JL, dan Stryer L, 2006. Biochemistry, $5^{\text {th }}$ ed., W. H. Freeman \& Co., New York.

Boyce A, Casey A, dan Walsh G, 2004. A Phytase Enzyme-Based Biochemistry Practical Particularly Suited to Student Undertaking Courses in Biotechnology and Environmental Science, Biochemistry and Molecular Biology Education, 32: 336-340.

Greiner R, Konietzny U, dan Jany KD, 1993. Purification and Characterization of Two Phytases from Escherichia coli, Archives of Biochemistry and Biophysics, 303: 107-113.
Greiner R dan Konietzny U, 2006. Phytase for Food Application, Food Technol. Biotechnol., 44(2): 125-140.

Gulati HK, Chadha BS, and Saini HS, 2007. Production and Characterization of Thermostable Alkaline Phytase from Bacillus laevolacticus Isolated from Rhizosphere Soil, $J$. Ind. Microbiol. Biotechnol., 34: 91-98.

Kim T, Mullaney EJ, Porres JM, Roneker KR, Crowe S, Rice S, Ko T, Ullah AHJ, Daly CB, Welch R, dan Lei XG, 2006. Shifting the $\mathrm{pH}$ Profile of Aspergillus niger PhyA Phytase To Match the Stomach $\mathrm{pH}$ Enhances Its Effectiveness as An Animal Feed Additive, Appl Environ Microbiol, 72(6): 4397-4403.

Kim YO, Kim HK, Bae KS, Yu JH, dan Oh TK, 1998. Purification and Properties of A Thermostable Phytase from Bacillus sp. DS11., Enzyme and Microbial Technology, 22: 2-7.

Kerovuo J, Lauraeus M, Nurminen P, Kalkkinen N, dan Apajalahti J, 1998. Isolation, Characterization, Molecular Gene Cloning, and Sequencing of a Novel Phytase from Bacillus subtilis, Applied and Environmental Microbiology, 64: 2079-2085.

Lott JN A, Ockenden I, Raboy V, dan Batten GD, 2000. Phytic Acid and Phosphorus in Crop Seeds and Fruits: A Global Estimate, Seed Science Research, 10: 11-33.

Nelson DL dan Cox MM, 2000. Lehninger Principles of Biochemistry, $3^{\text {rd }}$ ed, Worth Publishers, New York.

Ozusaglam A dan Ozcan N, 2009. Cloning of Phytase Gene in Probiotic Bacterium Bacillus coagulans, Advanced Studies in Biology, 1: 15-24.

Selle PH, Ravindran V, Caldwell RA, dan Bryden WL, 2000. Phytate and Phytase: Consequences for Protein Utilisation, Nutrition Research Reviews, 13: 255-278.

Singh B dan Satyanarayana T, 2009. Characterization of HAPPhytase from a Thermofhilic Mould Sporotrichum thermophile, Bioresource Technology, 100: 2046-2051.

Wang X, Upatham S, Panbangred W, Isarangkul D, Summpunn P, Wiyakrutta S, Meevootisom V, 2004. Purification, Characterization, Gene Cloning and Sequence Analysis of a Phytase from Klebsiella pneumoniae subsp. Pneumoniae XY-5, Science Asia, 30: 383-390

Wyss M, Brugger R, Kronenberger A, Remy R, Fimbel R, Oesterhelt G, Lehmann M dan van Loon APGM, 1999. Biochemical Characterization of Fungal Phytases (myoinositol hexakisphosphate phosphohydrolases): Catalytic Properties, Applied and Environmental Microbiology, 65: 367-373. 